\title{
Atypical anti-glomerular basement membrane disease with anti-GBM antibody negativity and ANCA positivity: a case report
}

\author{
$\mathrm{Na} \mathrm{Guo}{ }^{1 \dagger}$, Qinghua Yin ${ }^{1 \dagger}$, Song Lei ${ }^{2}$, Yanjun $\mathrm{He}^{2}$ and Ping Fu ${ }^{1 *}$ (D)
}

\begin{abstract}
Background: Anti-glomerular basement membrane (anti-GBM) disease is an organ-specific autoimmune disease that involves the lung and kidneys and leads to rapid glomerulonephritis progression, with or without diffuse alveolar hemorrhage, and even respiratory failure. Classic cases of anti-GBM disease are diagnosed based on the presence of the anti-GBM antibody in serum samples and kidney or lung biopsy tissue samples. However, atypical cases of anti-GBM disease are also seen in clinical practice.
\end{abstract}

Case presentation: We herein report the rare case of a patient with atypical anti-GBM disease whose serum was negative for the anti-GBM antibody but positive for the myeloperoxidase (MPO) anti-neutrophil cytoplasmic antibody (p-ANCA) and another atypical ANCA. Laboratory test results showed severe renal insufficiency with a creatinine level of $385 \mu \mathrm{mol} / \mathrm{L}$. Renal biopsy specimen analysis revealed 100\% glomeruli with crescents; immunofluorescence showed immunoglobulin G (lgG) linearly deposited alongside the GBM. Finally, the patient was discharged successfully after treatment with plasmapheresis, methylprednisolone and prednisone.

Conclusion: This patient, whose serum was negative for the anti-GBM antibody but positive for p-ANCA and another atypical ANCA, had a rare case of anti-GBM disease. Insights from this unusual case might help physicians diagnose rare forms of glomerulonephritis and treat affected patients in a timely manner.

Keywords: Anti-glomerular basement membrane disease, Goodpasture syndrome, Anti-neutrophil cytoplasmic antibody, Case report

\section{Background}

Anti-glomerular basement membrane (anti-GBM) disease, or Goodpasture syndrome, is an organ-specific autoimmune disease that involves the lung and kidneys and leads to the rapid progression of glomerulonephritis,

\footnotetext{
* Correspondence: fupinghx@scu.edu.cn

The authors Na Guo and Qinghua Yin contributed to the work equally and should be regarded as co-first authors.

'Kidney Research Institute, Division of Nephrology, West China Hospital,

Sichuan University, Chengdu 610041, China

Full list of author information is available at the end of the article
}

with or without diffuse alveolar hemorrhage, and even respiratory failure. Classic cases of anti-GBM disease are diagnosed based on the presence of anti-GBM antibodies in serum samples and kidney or lung biopsy tissue samples [1]. However, atypical cases of anti-GBM disease are also seen in clinical practice $[2,3]$. The case of the patient presented here, whose biopsy specimen analysis showed $100 \%$ crescents and immunoglobulin G (IgG) linearly deposited alongside the GBM and who repeatedly tested negative for serum anti-GBM antibodies but positive for the anti-myeloperoxidase (MPO) antibody

C C The Author(s). 2021 Open Access This article is licensed under a Creative Commons Attribution 4.0 International License, which permits use, sharing, adaptation, distribution and reproduction in any medium or format, as long as you give appropriate credit to the original author(s) and the source, provide a link to the Creative Commons licence, and indicate if changes were made. The images or other third party material in this article are included in the article's Creative Commons licence, unless indicated otherwise in a credit line to the material. If material is not included in the article's Creative Commons licence and your intended use is not permitted by statutory regulation or exceeds the permitted use, you will need to obtain permission directly from the copyright holder. To view a copy of this licence, visit http://creativecommons.org/licenses/by/4.0/. The Creative Commons Public Domain Dedication waiver (http://creativecommons.org/publicdomain/zero/1.0/) applies to the data made available in this article, unless otherwise stated in a credit line to the data. 
(p-ANCA) and another atypical ANCA, is unusual. Insights from this unusual case might help clinicians identify unusual features of glomerulonephritis and administer proper treatments in a timely manner.

\section{Case presentation}

A 48-year-old Chinese woman was administered a blood-activating and stasis-eliminating compound by a local physician for ankle pain. A "blood-activating and stasis-eliminating compound" is a type of traditional medicine that can be used as an analgesic and antipyretic. The ingredients of this blood-activating and stasiseliminating compound include safflower, dog ridge (made), mistletoe, herba lycopi leaf, spatholobi, caulis trachelospermi, cocklebur, Cyperus rotundus, Periploca sepium Bge, and natural copper (calcined). It does not cause an autoimmune response, such as rash or vasculitis. Edema and skin rashes in both lower limbs appeared 3 days after this treatment. She was further treated for edema with furosemide and spironolactone at the same local hospital, and she was transferred to our hospital in September 2019. She did not have diabetes, nor did she have any relevant family, life, or allergy history. At admission, her vital signs on physical examination were as follows: body temperature, $36.5^{\circ} \mathrm{C}$; blood pressure, 127/90 $\mathrm{mmHg}$; pulse, 71 beats/min; and respiratory rate, 20 breaths/min. Several round areas of the skin rash of varying sizes were seen on the arms, legs, and trunk. Pitting edema was observed in both lower limbs. Abdominal and cardiac exams showed no abnormalities.

The laboratory test results were as follows: urinary protein, 2+; blood protein, 3+; urinary protein excretion, $5.02 \mathrm{~g} / 24 \mathrm{~h}$; and creatinine, $385 \mu \mathrm{mol} / \mathrm{L}$ (Table 1). Further assessment revealed that the patient was positive for ANCAs by indirect immunofluorescence (a titer of 1 : 10), positive for p-ANCAs (a titer of 3.1 as the antibody index) by enzyme-linked immunosorbent assay (ELISA), and negative for both anti-GBM and anti-proteinase 3 (c-ANCA) antibodies after three repeated assays

Table 1 Laboratory characteristics

\begin{tabular}{|c|c|c|c|}
\hline Component & Value & Reference range & Interpretation \\
\hline \multicolumn{4}{|l|}{ Urinalysis results } \\
\hline Urinary protein & $2+$ & Negative & High \\
\hline Red blood Cells (n/HP) & 69 & $0-3$ & High \\
\hline White blood Cells (n/HP) & 1 & $0-5$ & Normal \\
\hline Urinary protein excretion ( $\mathrm{g} / 24 \mathrm{~h}$ ) & 5.02 & $<0.15$ & High \\
\hline $\mathrm{P} / \mathrm{Cr}$ ratio $(\mathrm{mg} / \mathrm{g})$ & 3869 & $<30$ & High \\
\hline Sugar sediment (mmol/L) & 0 & Negative & Normal \\
\hline \multicolumn{4}{|l|}{ Peripheral blood } \\
\hline Red blood cells $\left(\times 10^{12} / \mathrm{L}\right)$ & 3.11 & $3.8-5.1$ & Low \\
\hline Hemoglobin (g/L) & 91 & $115-150$ & Low \\
\hline White blood cells $\left(\times 10^{9} / \mathrm{L}\right)$ & 5.65 & $3.5-9.5$ & Normal \\
\hline Platelets $\left(\times 10^{9} / \mathrm{L}\right)$ & 128 & $100-300$ & Normal \\
\hline Neutrophils $\left(\times 10^{9} / L\right)$ & 4.02 & $1.8-6.3$ & Normal \\
\hline \multicolumn{4}{|l|}{ Chemistries } \\
\hline Serum creatinine $(\mu \mathrm{mol} / \mathrm{L})$ & 385 & $41-73$ & High \\
\hline Blood urea nitrogen (mmol/L) & 22.3 & $2.6-7.5$ & High \\
\hline Uric acid ( $\mu \mathrm{mol} / \mathrm{L})$ & 521 & $160-380$ & Normal \\
\hline eGFR (ml/min/1.73 m²) & 11.27 & $56-122$ & Low \\
\hline Total protein (g/L) & 54.2 & $65-85$ & Low \\
\hline Serum albumin (g/L) & 38.4 & $40-55$ & Low \\
\hline $\mathrm{Na}(\mathrm{mmol} / \mathrm{L})$ & 138.5 & $137-147$ & normal \\
\hline $\mathrm{K}(\mathrm{mmol} / \mathrm{L})$ & 5.63 & $3.5-5.3$ & High \\
\hline $\mathrm{Ca}(\mathrm{mmol} / \mathrm{L})$ & 1.89 & $2.11-2.52$ & Low \\
\hline$P(\mathrm{mmol} / \mathrm{L})$ & 0.90 & $0.85-1.51$ & normal \\
\hline C-reactive protein (mg/L) & 3.91 & $<5$ & Normal \\
\hline $\mathrm{PCT}(\mathrm{ng} / \mathrm{ml})$ & 0.14 & $<0.046$ & High \\
\hline
\end{tabular}

Abbreviations: $\mathrm{P} / \mathrm{C}$ ratio, $\mathrm{ALB} / \mathrm{Cr}$ (urinary), eGFR estimate glomerular filtration rate, $P C T$ procalcitonin 
Table 2 Serological data for antibodies

\begin{tabular}{lllll}
\hline & ANCA & p-ANCA & c-ANCA & anti-GBM \\
\hline Reference range & Negative & $<1.0$ & $<1.0$ & $<2.0$ \\
$2019 / 10 / 15$ & $\operatorname{pANCA}(+)(1: 10)$ & 3.1 & $<1.0$ & $<2.0$ \\
$2019 / 10 / 29$ & $\operatorname{pANCA}(+)(1: 10)$ & $<1.0$ & $<1.0$ & $<2.0$ \\
$2019 / 11 / 15$ & Negative & $<1.0$ & $<1.0$ & $<2.0$ \\
\hline
\end{tabular}

Abbreviations: ANCA Anti-neutrophil cytoplasmic antibodies, $p$-ANCA Antimyeloperoxidase ANCA, c-ANCA Anti-proteinase 3 ANCA, anti-GBM antiglomerular basement membrane antibodies

(Table 2). Computerized tomography (CT) revealed scattered areas of inflammation in both lungs, with a small amount of pericardial effusion and bilateral pleural effusion. Half a month later, CT showed no inflammation in either lung, and the pleural effusion had disappeared (Fig. 1). Renal ultrasonography showed normal-sized kidneys with elevated echogenicity.

Light microscopy on a Nikon ECLIPSE E-200 microscope (Nikon, Tokyo, Japan) revealed a total of 13 glomeruli, with three globally sclerotic glomeruli. Ten glomeruli had cellular crescents, and three had fibrocellular crescents, which suggested crescentic glomerulonephritis. The obliteration of Bowman's capsules and segmental sclerotic lesions were noted in 5 glomeruli. In addition, tubular atrophy (30\%) was accompanied by interstitial fibrosis (30\%), with the interstitial infiltration of lymphocytes, monocytes, and plasmocytes (Fig. 2a, b, c). Immunofluorescence was observed under Olympus BX41microscope (Olympus, Tokyo, Japan) to assess five glomeruli, which showed IgG linearly deposited alongside the GBM (Fig. 3). Electron microscopy (EM) performed with a transmission electron microscope (JEOL Ltd., Tokyo, Japan) showed the collapse and rupture of the GBM in the presence of foot process fusion. The absence of electron-dense deposits was another EM hallmark of the disease (Fig. 4a, b). Therefore, a diagnosis of anti-GBM disease with positivity for p-ANCA and another atypical ANCA was established, despite repeated negative serum anti-GBM antibody test results.

After the diagnosis of anti-GBM disease was established based on the clinical features and biopsy findings in our patient, treatment with methylprednisolone and plasmapheresis was initiated immediately. The treatment was initiated with $500 \mathrm{mg}$ of intravenous high-dose methylprednisolone, which was administered three times, followed by oral prednisone at $50 \mathrm{mg}$ per day. A hemodialysis catheter was implanted in the right femoral vein to enable plasmapheresis every 2 days (ten sessions in all). Interestingly, positivity for p-ANCA disappeared, but the patient was still positive for total ANCAs after the fourth session of plasmapheresis; the patient was negative for both c-ANCA and anti-GBM antibodies at admission. However, no signals for total ANCA or antiGBM antibodies were observed after ten sessions of plasmapheresis.

The patient had good tolerance of all drugs and procedures and was successfully discharged after medical care. She was followed up via outpatient visits to continue treatment with prednisolone and cyclophosphamide. Additionally, her kidney function and lung disease were regularly monitored in specialized departments.

\section{Discussion and conclusion}

Anti-GBM disease represents a rarely encountered pulmonary-renal disorder that manifests as the rapid progression of glomerulonephritis and alveolar hemorrhage. The pathogenesis of anti-GBM disease involves anti-GBM antibodies in the blood that target the $\alpha-3$ chain of collagen IV in the glomerular and/or alveolar basement membranes [3]. An elevated serum level of anti-GBM antibodies guides the diagnostic process. However, a tissue biopsy sample showing a linear pattern of antibody deposition along the basement membranes of kidney glomeruli, with or without alveoli

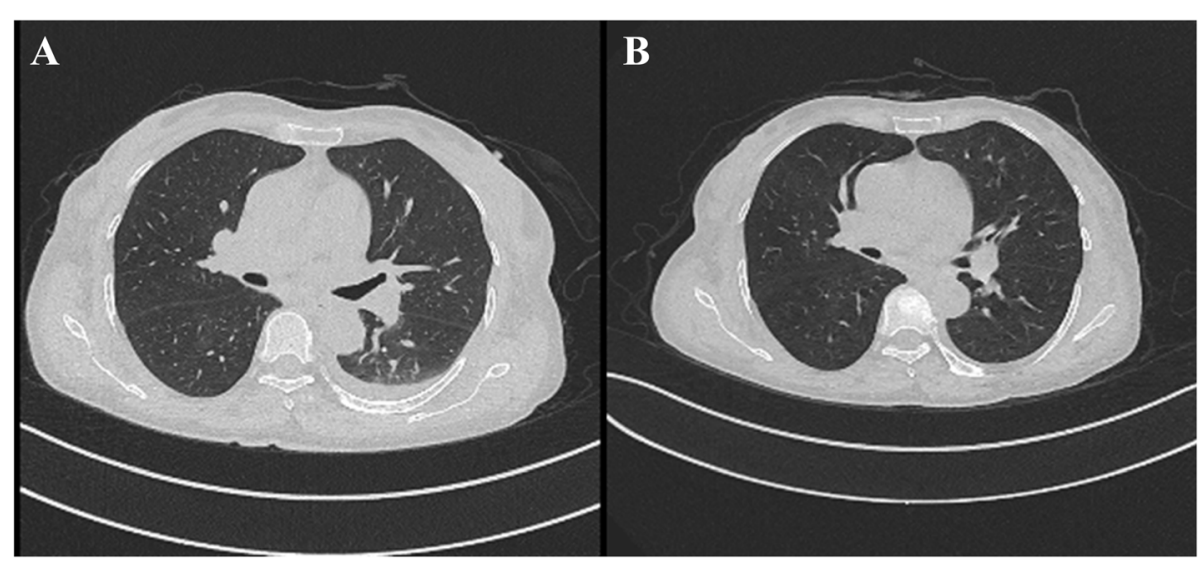

Fig. 1 Computerized tomography (CT) images of the lungs. a, October 29; b, November 14 


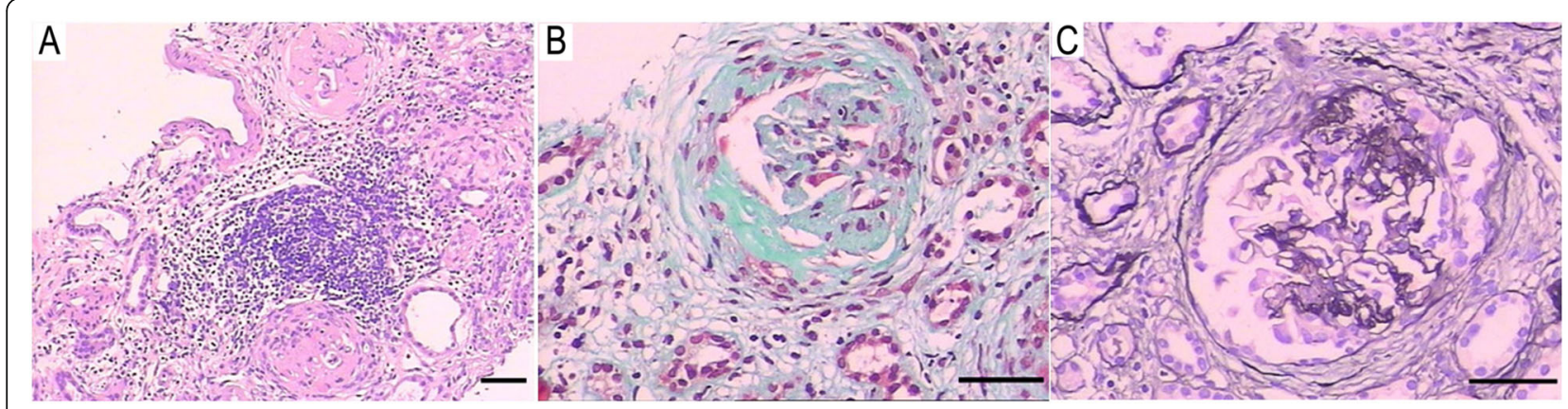

Fig. 2 Light microscopy. a, Hematoxylin and eosin (HE) staining showed globally sclerotic glomeruli and the infiltration of inflammatory cells ( $x$ 100); b, Masson's trichrome staining showed a large circumferential crescent (Masson $\times 200$ ); c, The use of periodic acid-silver methenamine (PASM) stain identified the rupture of the glomerular basement membrane $(\mathrm{GBM})$ and a small circumscribed crescent $(\times 200)$. Scale bars $=50 \mu \mathrm{m}$

showing this pattern of antibody deposition, is considered an important indicator confirming the diagnosis of anti-GBM disease [4]. This is especially critical in patients with suspected anti-GBM disease whose serum is negative for anti-GBM antibodies. The patient, whose repeated anti-GBM antibody tests were negative, was positive for anti-GBM antibodies according to immunofluorescence in a renal biopsy sample. Moreover, her serum was positive for anti-MPO antibodies and another atypical ANCA. Thus, we are the first to report this unusual presentation of anti-GBM disease.

Several factors may explain the negative ELISA results in patients with anti-GBM disease. First, highaffinity autoantibodies can be trapped in the kidneys or lung, which results in amounts of anti-GBM antibodies in the blood below the level necessary for detection by ELISA, as previously reported in patients with anti-GBM antibody disease [5-7]. In addition, ELISA techniques used to detect anti-GBM antibodies

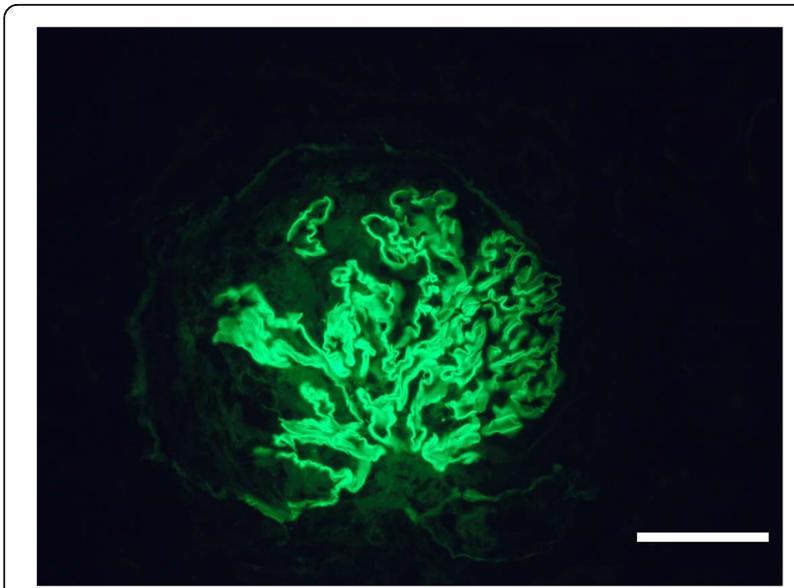

Fig. 3 Immunofluorescence. Immunofluorescence for immunoglobulin $\mathrm{G}$ revealed linear deposits along the GBM. Scale bars $=50 \mu \mathrm{m}$ could give false-negative results, despite their high sensitivity (>95\%) and specificity (>97\%) [8]. Another possibility is that the average dissociation rate constant $\left(K_{\text {diss }}\right)$ of the antibodies might be unusually high; although these antibodies can bind to the GBM, in the ELISA, they can dissociate during the washing period [7]. In our opinion, the first mechanisms described above are more likely the explanations for the negative results. Thus, a negative serum anti-GBM antibody test is not sufficient to rule out anti-GBM disease. Kidney or lung biopsy is required to confirm or exclude the diagnosis of anti-GBM disease in patients with a high level of clinical suspicion whose serum is negative for anti-GBM antibodies.

Crescentic glomerulonephritis in the setting of elevated ANCA and anti-GBM titers is referred to as a double-positive disease. Approximately one-third of all patients with anti-GBM antibodies are also positive for ANCAs, generally myeloperoxidase ANCAs [9]. A multicenter study that included 646 patients from four centers in three European countries showed that $5.7 \%$ of patients were double-positive, with $70 \%$ of them positive for p-ANCA [10]. There are currently no reports of positivity for atypical ANCAs in patients with anti-GBM disease. The present patient was diagnosed with anti-GBM disease on the basis of the presence of anti-GBM antibodies in a kidney biopsy sample and anti-MPO antibodies and atypical ANCAs in a blood sample. Patients with double-positive disease have extrarenal signs comparable to those of patients with ANCA-associated vasculitis. At the same time, the renal symptoms of double-positive disease mimic those of anti-GBM disease at the clinical and histological levels [11]. Similarly, the renal signs in our patient were hematuria, proteinuria, elevated serum creatinine, and pathological changes in biopsy samples indicative of anti-GBM disease. In contrast, the extrarenal manifestations were ankle pain and 

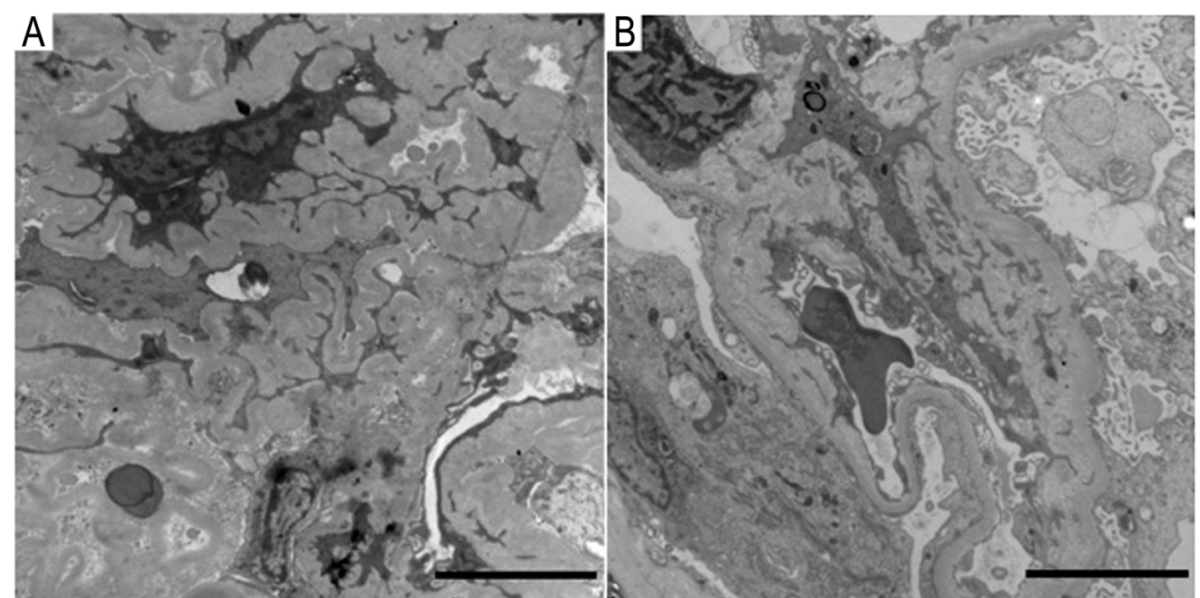

Fig. 4 Electron microscopy. Electron microscopy findings showed the collapse and rupture of the GBM with the presence of foot process fusion. The absence of electron-dense deposits was another EM hallmark of the disease. Scale bars $=50 \mu \mathrm{m}$

areas of skin rash on the arms, limbs and trunk, which are indicative of ANCA-associated vasculitis.

Therapy for double-positive anti-GBM disease is comparable to that for single-positive anti-GBM disease, which involves high-dose glucocorticoids, cyclophosphamide, and plasmapheresis [4]. Once the diagnosis of anti-GBM disease is established, plasmapheresis should be performed to remove circulating pathogenic antibodies. At the same time, cyclophosphamide and prednisone are recommended to prevent further autoantibody production and attenuate the inflammation. Plasmapheresis and methylprednisolone were initiated immediately in our patient after the diagnosis of anti-GBM disease was made on the basis of biopsy. The circulating autoantibodies were cleared after ten sessions of plasmapheresis.

A few limitations of our study are important to mention. First, we did not carry out an immunoassay to quantitate MPO because there was no extra tissue available. Second, an insufficient amount of the patient's serum was available, which meant that a Western blot for anti-GBM antibodies could be performed. Finally, the reason two antibodies, p-ANCA and atypical ANCA, appeared in the same serum sample may need further exploration.

In conclusion, cases of anti-GBM disease in patients whose serum is negative for anti-GBM antibodies and positive for ANCAs are clinically sporadic. The use of ELISA to detect anti-GBM antibodies can yield false-negative results. Thus, negative serum anti-GBM antibody test results are not sufficient to rule out anti-GBM disease. Kidney or lung biopsy is needed to confirm or exclude anti-GBM disease in patients with a high degree of clinical suspicion whose serum is negative for anti-GBM antibodies. Insights from this unusual case might help physicians diagnose a rare form of glomerulonephritis and treat affected patients in a timely manner.

\section{Abbreviations \\ Anti-GBM: Anti-Glomerular Basement Membrane; ANCA: Anti-Neutrophil Cytoplasmic Antibody; MPO: Myeloperoxidase; p-ANCA: Anti- Myeloperoxidase ANCA; c-ANCA: Anti-Proteinase 3 ANCA; ELISA: Enzyme- Linked Immunosorbent Assay; CT: Computerized Tomography; IgG: Immunoglobulin G}

\section{Acknowledgments}

We appreciate the patient and her husband for participating in this study.

\section{Authors' contributions}

NG and QY collected all the data, carried out the analysis of the patient's clinical course and outcome and were also involved in drafting the manuscript. SL and YH were responsible for the pathology images and legends. PF established the diagnosis and revised and approved the final manuscript. Each author contributed important intellectual content during the drafting and revision of the manuscript. All the authors read and approved the final version of the manuscript to be published.

\section{Funding}

This study was supported by the 1.3.5 Project for Disciplines of Excellence, West China Hospital, Sichuan University (No. ZYGD18027). The funding body guided the design of the study, collection, analysis, and interpretation of data and revised the manuscript before submission. The funder also supported all costs associated with the study, including the fees upon acceptance for publication.

\section{Availability of data and materials \\ The datasets used in this study are available from the corresponding author on reasonable request.}

\section{Ethics approval and consent to participate}

The patient and her husband were informed about the availability and importance of the data, including the clinical data, images, and health information, described in this article.

\section{Consent for publication}

Written informed consent was obtained from the patient and her husband for the publication of this case report and any accompanying images. A 
copy of the written consent is available for review by the Editor of this journal.

\section{Competing interests}

The authors declare that they have no competing interests.

\section{Author details}

'Kidney Research Institute, Division of Nephrology, West China Hospital, Sichuan University, Chengdu 610041, China. ${ }^{2}$ Department of Pathology, West China Hospital, Sichuan University, Chengdu 610041, China.

Received: 8 May 2020 Accepted: 4 January 2021

\section{Published online: 05 February 2021}

\section{References}

1. Greco A, Rizzo MI, De Virgilio A, Gallo A, Fusconi M, Pagliuca G, Martellucci S, Turchetta R, Longo L, De Vincentiis M. Goodpasture's syndrome: a clinical update. Autoimmun Rev. 2015;14(3):246-53. https://doi.org/10.1016/j.autrev. 2014.11.006

2. Le Flecher A, Viallet N, Hebmann D, Chauveau B, Vacher CH. Atypical antiglomerular basement membrane disease presenting as macroscopic hematuria, loin pain and acute kidney injury after intensive exercise. Clin Kidney J. 2019;12(6):801-2. https://doi.org/10.1093/ckj/sfz044.

3. Troxell ML, Houghton DC. Atypical anti-glomerular basement membrane disease. Clin Kidney J. 2016;9(2):211-21. https://doi.org/10.1093/ckj/sfv140.

4. Smith C, Dhaliwal G, Saint S, Farkash EA, Garg P. Double Trouble. N Engl J Med. 2019;381(19):1854-60. https://doi.org/10.1056/NEJMcps1810654.

5. Berends-De Vries T, Boerma S, Doornabal J, Dikkeschei B, Stegeman C, Veneman T. Goodpasture's Syndrome with Negative Anti-glomerular Basement Membrane Antibodies. Eur J Case Rep Intern Med. 2017;2(LATEST ONLINE):687. https://doi.org/10.12890/2017_000687.

6. Rutgers A, Meyers KE, Canziani G, Kalluri R, Lin J, Madaio MP. High affinity of anti-GBM antibodies from Goodpasture and transplanted Alport patients to alpha3(IV)NC1 collagen. Kidney Int. 2000;58(1):115-22. https://doi.org/10. 1046/j.1523-1755.2000.00146.x.

7. Salama AD, Dougan T, Levy JB, Cook HT, Morgan SH, Naudeer S, Maidment G, George AJ, Evans D, Lightstone L, et al. Goodpasture's disease in the absence of circulating anti-glomerular basement membrane antibodies as detected by standard techniques. Am J Kidney Dis. 2002;39(6):1162-7. https://doi.org/10.1053/ajkd.2002.33385.

8. Shiferaw B, Miro V, Smith C, Akella J, Chua W, Kim Z. Goodpasture's Disease: An Uncommon Disease With an Atypical Clinical Course. J Clin Med Res. 2016;8(1):52-5. https://doi.org/10.14740/jocmr2379w.

9. Levy JB, Hammad T, Coulthart A, Dougan T, Pusey CD. Clinical features and outcome of patients with both ANCA and anti-GBM antibodies. Kidney Int. 2004;66(4):1535-40. https://doi.org/10.1016/j.kint.2017.03.014.

10. McAdoo SP, Tanna A, Hruskova Z, Holm L, Weiner M, Arulkumaran N, Kang A, Satrapova V, Levy J, Ohlsson S, et al. Patients double-seropositive for ANCA and anti-GBM antibodies have varied renal survival, frequency of relapse, and outcomes compared to single-seropositive patients. Kidney Int. 2017;92(3):693-702. https://doi.org/10.1016/j.kint.2017.03.014.

11. Srivastava A, Rao GK, Segal PE, Shah M, Geetha D. Characteristics and outcome of crescentic glomerulonephritis in patients with both antineutrophil cytoplasmic antibody and anti-glomerular basement membrane antibody. Clin Rheumatol. 2013;32(9):1317-22. https://doi.org/10. 1007/s10067-013-2268-5.

\section{Publisher's Note}

Springer Nature remains neutral with regard to jurisdictional claims in published maps and institutional affiliations.

Ready to submit your research? Choose BMC and benefit from:
- fast, convenient online submission
- thorough peer review by experienced researchers in your field
- rapid publication on acceptance
- support for research data, including large and complex data types
- gold Open Access which fosters wider collaboration and increased citations
- maximum visibility for your research: over 100M website views per year
At BMC, research is always in progress.
Learn more biomedcentral.com/submissions

